\title{
Perceptions of Maritime Faculty of the University of Saint Anthony on the Shift of Traditional to Online Instruction
}

\author{
Estrella Arroyo ${ }^{1 *}$, Christopher A. Britanico ${ }^{2}$ \\ ${ }^{1,2}$ University of Saint Anthony Iriga City, Philippines \\ * Corresponding Author. E-mail : stararroyo.dean@yahoo.com
}

\begin{abstract}
This study focused on the perceptions of Maritime faculty of the University of Saint Anthony, Iriga City Philippines, on the shift of traditional to online instruction since the pandemic in March 2020 to the present.It is a purely qualitative study, a case study to specific, that used coding as its method to interpret and analyze the data gathered from unstructured interviews of the selected faculty of the Maritime department. Further, the study identified the experiences and challenges that confronted the faculty members; thus, enabled the researchers to arrive at conclusions and render recommendations. The findings of the study showed that Maritime faculty experiences on online instruction were deeply rooted on practicality and accessibility. It is both refreshing and difficult to do accordingly. The challenges were mostly tied to resources and investments used by the faculty during online interaction. This study shall become a basis for the implementation of new policies in the department in terms of faculty development, materials development and formulation of teaching strategies.
\end{abstract}

Keywords: Instruction, Online, Perceptions, Traditional

\section{INTRODUCTION}

The ongoing Covid-19 pandemic brought widespread change to the entire world. One of these changes is the shift to from the traditional method of instruction and learning to online classes. They happened abruptly and swiftly and teachers were left with no choice, but to prepare for the inevitable. Teachers feared online instruction due to several unknowns. (Baralt et al., 2016) believe that online learning may be less effective than classroom learning as students are less engaged, so the prospect of teaching online becomes a great challenge to most, if not all, teachers.

The University of Saint Anthony Maritime department is currently on its $2^{\text {nd }}$ year of delivering online learning. Based (Bacus, n.d.) defines flexible learning as a pedagogical approach allowing flexibility of time, place, and audience including, but not solely focused on the use of technology. The Maritime Department delivers flexible learning through purely online instruction. Further, it uses was learning management systems (LMS), both proprietary and nonproprietary, as well as alternative learning guides. The department also utilizes synchronous and asynchronous activities both for instruction and assessment.

It can be claimed that the Maritime department implemented measures to prepare the students as well as the teachers for the shift to online instruction. Even 
with adequate preparation, there are still multiple variables that could influence a teacher's delivery of online instruction. With this premise, this study was undertaken to explore the experiences and challenges met by Maritime faculty on the "before," "during" and "after" the implementation of online learning in the university.

This study attempts to scrutinize the perceptions of Maritime faculty on the abrupt shift to online instruction from traditional method.

Specifically, it seeks answers to the following questions: What are the experiences of USANT Maritime faculty members on the shift from traditional teaching to online instruction?, What are the difficulties encountered by these faculty members?, What recommendations can be made based on the findings of the study?

\section{LITERATURE REVIEW}

From the reviewed studies, the following similarities and differences are gleaned: Based on the studies of Bergamin et al., 2012, Wanner \& Palmer, 2015, Xu \& Jaggars, 2014, Korolkov et al., 2020, discussed the current state of flexible learning. It included its advantages and disadvantages and the experiences of students and teachers during flexible learning. The studies of Khe F.H. and Wing S.C. 2014 (Cui et al., 2014), Conaway et al., 2005, Kebritchi et al., 2017, Sammons \& Ruth, 2007, Duncan and Barret 2009, Rasheed et al., 2020 and Grgurović, 2014 all discussed the shift to online classes and how its affects the students.

\section{Research Gap}

From the review of related studies and literature it could be gleaned that no one has ventured yet on perceptions and experiences of Maritime faculty on the shift to online instruction. This is the gap being addressed by the present study. Hence, the present study is not a duplication of developed and published or unpublished materials based from the reviewed studies.

\section{RESEARCH METHODOLOGY}

This research will use case study, a type of qualitative research. A Case study is a detailed examination of an event (or series of related events) which the analyst believes that there is an operation of some identified general theoretical principles. This study also uses information from the faculty of Maritime department who previously taught face-to-face then changed to online instruction.

\section{Participants}

Participants were selected from the faculty of the Maritime department. The researchers considered the participants of the study as key informants because they have first-hand knowledge and experience of the topic of the research; hence, a good source of detailed information. 


\section{Sampling}

The researchers of the study used non-probability sampling, specifically purposive sampling. This sampling method is based on the characteristics of a population and the objective of the study. With purposive sampling, the researchers relied on their own judgement when it comes to choosing the members of the population to participate in the study.

\section{Data Gathering Tools}

This study will use unstructured interview, the participants answer the questions based on what they personally think and feel about the topic. There are no suggested answers. The responses will be purely dependent on the participants decision-making skills, giving them opportunity to think critically about the questions.

\section{Data Analysis}

The researchers will use coding to analyse the data from gathered from the participants. Coding is the act of using symbols like words to represent arbitrary or subjective data (emotions, opinions, attitudes) to ensure secrecy or privacy of data. The data will be collated in order to bring together the coded data. The data was given an orderly appearance by putting it a graph. The study will also employ a similarity matrix, the responses will be written in a table of cases and their associated variables.

\section{RESULTS AND DISCUSSION}

The data acquired and results derived are illustrated in transcriptions. Questions given during the online interview process is adjusted and modified according to the statement of the problem.

\section{A. Key Informant A}




\begin{tabular}{|c|c|c|}
\hline RAW DATA & PRELIMINARY CODING & FINAL CODE \\
\hline $\begin{array}{l}\text { It is varying at most. In asking for } \\
\text { technical support, mostly asking for } \\
\text { internet connectivity from MIS. Time } \\
\text { is mostly wasted because of power } \\
\text { outages and weak internet connection. } \\
\text { Whatever instructional strategies used } \\
\text { by instructors the students will just } \\
\text { resort to the most available solutions on } \\
\text { line, the copy and paste techniques. }\end{array}$ & $\begin{array}{l}\text { - Increased awareness on } \\
\text { the need for patience } \\
\text { and other virtues. } \\
\text { - Synchronous teaching } \\
\text { is mostly effective } \\
\text { - Factors such as power } \\
\text { outages serve as } \\
\text { hindrance to online } \\
\text { education }\end{array}$ & $\begin{array}{lr}\text { - } & \text { Adaptation } \\
\text { expected } & \text { is } \\
\text { Maritime } & \text { faculty } \\
\text { members } & \end{array}$ \\
\hline $\begin{array}{l}\text { Still, I believe my role is to be effective } \\
\text { in acting as a facilitator. Likewise, } \\
\text { increased patience, understanding and } \\
\text { leniency to the students who make "no } \\
\text { internet connection or internet signal" } \\
\text { their excuse whenever they don't want } \\
\text { to attend the class is a must. Financial } \\
\text { and time adjustment also, because the } \\
\text { students will ask you about any } \\
\text { concerns anytime they like! } \\
\text { Synchronous is effective but has certain } \\
\text { downfalls, that's why I have to keep } \\
\text { adapting as an instructor and do my } \\
\text { part properly. }\end{array}$ & & \\
\hline
\end{tabular}

\section{Data Coding of Guide Questions ( $1^{\text {st }}$ set):}

\section{Interpretation:}

Informant A believes that the lived experience of teaching under USANT's maritime department is best comprehended when the instructor embodies characteristics necessary for one's adaptation to the online curriculum. Increased patience and leniency are a must and must therefore be put into practice in order to effectively teach SYCHRONOUSLY. These factors are crucial in combating the drastic and long-lasting effects of interrupting factors such as weak internet connection and power outages during the pandemic, and is hence, measured and practiced alongside one's perception of effectively teaching and educating maritime students accordingly.

\begin{tabular}{lll}
\hline \multicolumn{1}{c}{ RAW DATA } & $\begin{array}{l}\text { PRELIMINARY } \\
\text { CODING }\end{array}$ & FINAL CODE \\
\hline $\begin{array}{l}\text { There's nothing much to say } \\
\text { because I already said it. Aside } \\
\text { from the inferior internet } \\
\text { services, there is no further }\end{array}$ & $\bullet \begin{array}{ll}\text { Hindrances exist } \\
\text { amidst online } \\
\text { difficulties. }\end{array}$ & $\begin{array}{l}\text { education } \\
\text { Validation of } \\
\text { hindrances } \\
\text { as internet connections are } \\
\text { becoming inclusive for } \\
\text { online education }\end{array}$ \\
\\
\end{tabular}

\section{Data Coding of Guide Questions ( $2^{\text {nd }}$ set):}

Interpretation:

Much like the previous claim, internet connection problem is prevalent due to the standards of telecommunication companies and ISPs (Internet service providers) in the country. As a result, synchronous teaching is obstructed. 


\section{B. Key Informant B}

Data Coding of Guide Questions ( $1^{\text {st }}$ set):

\begin{tabular}{|c|c|c|}
\hline RAW DATA & $\begin{array}{l}\text { PRELIMINARY } \\
\text { CODING }\end{array}$ & FINAL CODE \\
\hline $\begin{array}{l}\text { 1. I provide basic tech support for } \\
\text { other teachers and I. In } \\
\text { accordance with time } \\
\text { management, time is wasted due } \\
\text { to poor connection and } \\
\text { blackouts. We still require } \\
\text { specific techs and devices to } \\
\text { fully deliver our best in } \\
\text { teaching. Rest assured, we will } \\
\text { still continue to relay our } \\
\text { abilities especially in tech } \\
\text { support, hence, I have adjusted } \\
\text { myself to be better with } \\
\text { technology, but at times it's too } \\
\text { stressful - even in health. } \\
\text { I continue to improve myself } \\
\text { regardless of the situation } \\
\text { education is in. }\end{array}$ & 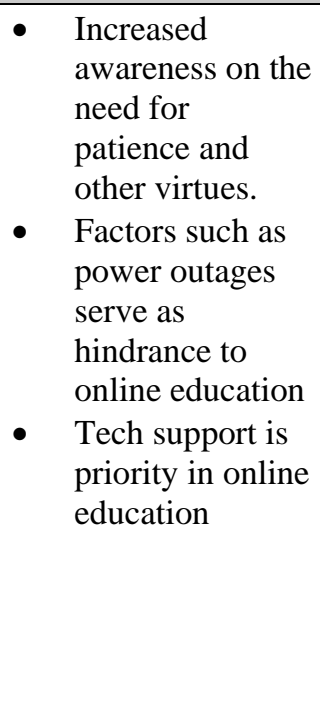 & $\begin{array}{l}\text { Technology is an } \\
\text { asset for effective } \\
\text { online education. }\end{array}$ \\
\hline
\end{tabular}

\section{Interpretation:}

Informant B avers that technology is crucial to teach in the $21^{\text {st }}$ century amidst the COVID-19 pandemic. The responsibilities remain the same despite shifting to online education hence, adaptation is a must whilst offering ample time in learning technology is a prerequisite for any instructor of any course.

Furthermore, the informant claims that the lack of specific devices and techs essential for the maritime department of USANT is still present, and that this predicament is a given since major adjustments have been made in order to create an online channel for education to flow in.

\begin{tabular}{|c|c|c|}
\hline RAW DATA & $\begin{array}{l}\text { PRELIMINARY } \\
\text { CODING }\end{array}$ & FINAL CODE \\
\hline $\begin{array}{l}\text { There are many difficulties. The } \\
\text { internet connections of students } \\
\text { and instructors, cheating during } \\
\text { assessments and data storage in } \\
\text { G-drive is too limited especially } \\
\text { for students who lack finances } \\
\text { for online software and even } \\
\text { their devices. }\end{array}$ & 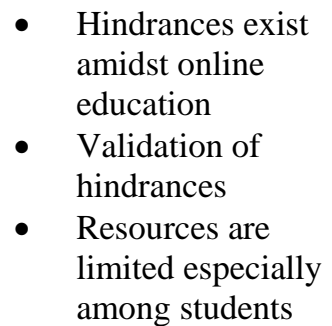 & $\begin{array}{l}\text { The difficulties } \\
\text { of online } \\
\text { education is } \\
\text { rooted on basic } \\
\text { needs, resources } \\
\text { and essentials. }\end{array}$ \\
\hline
\end{tabular}

\section{Data Coding of Guide Questions ( $2^{\text {nd }}$ set $)$ :}

Interpretation

Most difficulties are truly interlapped with digital assets. This involves internet connections, power outages, rampant cheating due to absence of direct facilitation and limited online storage space. 
While they may be fixable, inconsistence is primarily the issue due to the lack of sufficient resources and knowledge on procuring online needs. As such, the pervasive hindrances outweigh the value of teaching respectively, especially for those under the maritime course of USANT.

\section{Key Informant C}

Data Coding of Guide Questions ( $1^{\text {st }}$ set $)$ :

\begin{tabular}{|c|c|c|}
\hline RAW DATA & $\begin{array}{l}\text { PRELIMINARY } \\
\text { CODING }\end{array}$ & FINAL CODE \\
\hline $\begin{array}{l}\text { The experience is both new and } \\
\text { difficult. In time management, we } \\
\text { often are flexible but are sometimes } \\
\text { limited by what we can teach online } \\
\text { due to difficulties like power } \\
\text { outages. While we still do our part as } \\
\text { instructors, we still consider that fact } \\
\text { that we have to be knowledgeable of } \\
\text { technology. For strategies, I'm } \\
\text { practical of what I can do and what I } \\
\text { have because I know it's difficult for } \\
\text { most students as well. }\end{array}$ & $\begin{array}{l}\text { Increased awareness } \\
\text { on the need for } \\
\text { knowledge on } \\
\text { technology. } \\
\text { Factors such as } \\
\text { power outages serve } \\
\text { as hindrance to } \\
\text { online education } \\
\text { Being practical is } \\
\text { essential for online } \\
\text { instruction. }\end{array}$ & $\begin{array}{l}\text { Fulfilling one's duty as } \\
\text { an instructor through } \\
\text { practical means and } \\
\text { ends. }\end{array}$ \\
\hline $\begin{array}{l}\text { I do my best as a faculty member of } \\
\text { USANT's maritime department. }\end{array}$ & & \\
\hline
\end{tabular}

\section{Interpretation:}

Informant $\mathrm{C}$ follows the same thought-process as the previous two: in that one's performance as an instructor is measured by what is presented to them, as well as what is available in the work field. Initially, difficulties remain pervasive albeit such predicament can be countered by integrating practical teaching strategies and patience during instruction. The shift in teaching and facilitating is truly felt by the informant. As such, the key to "navigate around such travesty is to be understanding of possible situations instigated by the pandemic towards online education.

Data Coding of Guide Questions ( $2^{\text {nd }}$ set):

\begin{tabular}{|c|c|c|}
\hline RAW DATA & $\begin{array}{l}\text { PRELIMINARY } \\
\text { CODING }\end{array}$ & FINAL CODE \\
\hline $\begin{array}{l}\text { Internet connections for school } \\
\text { and students, health protocols } \\
\text { when we need students to be at } \\
\text { the department at times, power } \\
\text { outages and student's lack of } \\
\text { access to devices and learning } \\
\text { materials. }\end{array}$ & $\begin{array}{l}\text { - Hindrances exist amidst } \\
\text { online education } \\
\text { - Validation } \\
\text { hindrances } \\
\text { - Power outages, limited } \\
\text { access to learning } \\
\text { materials } \\
\text { - Absence of necessary } \\
\text { devices. }\end{array}$ & $\begin{array}{l}\text { - Palpable hindrances } \\
\text { are too rampant; } \\
\text { involving power } \\
\text { outages and internet } \\
\text { connections as } \\
\text { primary factors. }\end{array}$ \\
\hline
\end{tabular}

\section{Interpretation:}

Like the other 2, Informant $\mathrm{C}$ states that internet connection and power outages affect the instructor's quality of teaching. This too, is true for both students and instructors alike. 
Additionally, even the lack of devices (laptops, smartphones, etc.) is present among a certain percentage of students. While most devices can be offered by the school to instructors, the same cannot be said of students especially in far-off areas and communities in Camarines Sur.

\section{Key Informant D}

\begin{tabular}{|c|c|c|}
\hline RAW DATA & $\begin{array}{l}\text { PRELIMINARY } \\
\text { CODING }\end{array}$ & FINAL CODE \\
\hline $\begin{array}{l}\text { It's hard and stressful. When we } \\
\text { have weak internet, time is affected } \\
\text { heavily, and even during power } \\
\text { outages in Iriga, we become } \\
\text { confused of our obligations. } \\
\text { I still believe we have to be good } \\
\text { instructors to maritime students } \\
\text { because we are tasked with this } \\
\text { responsibility }\end{array}$ & 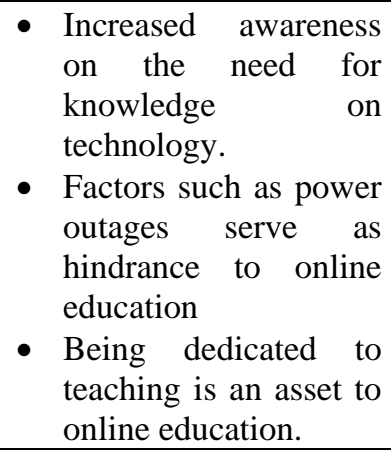 & $\begin{array}{l}\text { - Difficult times are } \\
\text { present in difficult } \\
\text { situations; such is } \\
\text { true for online } \\
\text { education. }\end{array}$ \\
\hline
\end{tabular}

Data Coding of Guide Questions ( $1^{\text {st }}$ set):

Interpretation:

Informant $\mathrm{D}$ is steadfast with her claim on remaining vigilant and driven during online education amidst the pandemic. Such task is a test on how an instructor must perform and test his/her mettle with the holistic end of educating students accordingly.

However, this endeavor is "snagged" by already-mentioned hindrances which are detrimental in effectively performing the obligation present for both student and instructor.

Data Coding of Guide Questions ( $2^{\text {nd }}$ set $)$ :

\begin{tabular}{|c|c|c|}
\hline RAW DATA & $\begin{array}{l}\text { PRELIMINARY } \\
\text { CODING }\end{array}$ & FINAL CODE \\
\hline $\begin{array}{l}\text { Like I have said before, internet } \\
\text { connection is too weak sometimes, } \\
\text { Iriga has a bad history in } \\
\text { maintaining stability in electrical } \\
\text { power and teaching online is } \\
\text { stressful especially to my mental and } \\
\text { physical health. }\end{array}$ & 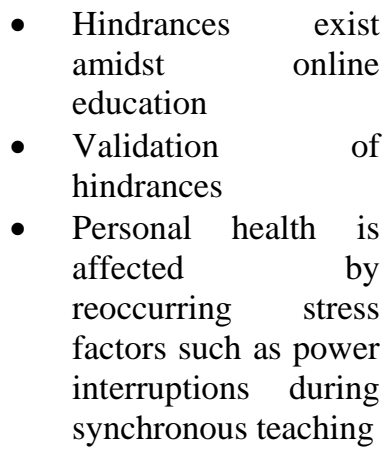 & $\begin{array}{l}\text { - Palpable hindrances } \\
\text { are too rampant; } \\
\text { involving power } \\
\text { outages and internet } \\
\text { connections as } \\
\text { primary factors. }\end{array}$ \\
\hline
\end{tabular}

\section{Interpretation:}

Like the others, stressful factors such as poor internet connection is felt alongside unfavorable power interruptions. The frequent mentioning of these factors reveals that they are the most felt, and are thus, the most intrusive of them all. Additionally, it is believed that the personal health of the instructor is significantly affected by the nature of online teaching, with it taking a toll on 
physical and mental health respective to the instructor's maximum capacity and reserves.

\section{E. Key Informant E}

Data Coding of Guide Questions ( $1^{\text {st }}$ set):

\begin{tabular}{l} 
RAW DATA \\
\hline 1 , Mostly, it is very strenuous but it \\
can also be exciting and convenient.
\end{tabular}

Managing time is both stressful and convenient because we can instruct on our own way while being in the comfort of our own control and management. Personally, I am good with handling devices and understanding software so I think I'm doing good.

We always want to always make it a habit of being sharp and strict with out teaching despite restrictions, but there are so many factors that interrupt as during our work like bad internet connections and more.

\section{Interpretation:}

Informant $\mathrm{E}$ is confident that the shift to online education is both convenient and difficult for some and him. The convenience lies on the flexibility of the instructor to update instructions and teach via the comfort of his own control and capacity. This is also true for maritime students of the current year. While such idea is true, difficulties just as what is mentioned before is still felt; usually in the form of poor internet connection and the like.

\begin{tabular}{|c|c|c|c|}
\hline RAW DATA & $\begin{array}{l}\text { PRELI } \\
\text { CODII }\end{array}$ & INARY & FINAL CODE \\
\hline $\begin{array}{l}\text { Poor internet connections, constant } \\
\text { power interruptions. Sometimes no } \\
\text { warnings or announcements, } \\
\text { stressful teaching due to health } \\
\text { problems caused by excessive } \\
\text { exposure to radiation and more. }\end{array}$ & $\begin{array}{ll}\text { - } & \text { Hindrances } \\
\text { amidst } \\
\text { education } \\
\text { - } \quad \text { Validation } \\
\text { hindrances } \\
\text { - } \begin{array}{l}\text { Personal } \\
\text { affected }\end{array}\end{array}$ & $\begin{array}{l}\text { exist } \\
\text { online } \\
\text { of } \\
\text { alth is }\end{array}$ & $\begin{array}{l}\text { - Hindrances remain } \\
\text { consistent and felt } \\
\text { throughout the } \\
\text { course of the online } \\
\text { education } \\
\text { curriculum. }\end{array}$ \\
\hline
\end{tabular}

USANT's maritime department is known for its strict and meticulous teaching personnel who seek to discipline their students through educative and effective means. This, according to informant E's insinuation, is still passed despite the shift to online education.

Data Coding of Guide Questions ( $2^{\text {nd }}$ set):

Interpretation: 
Informant $\mathrm{E}$ follows the usual pattern of reported difficulties: ranging from poor internet connection, power outages, and personal health due to overuse and exposure to the use of gadgets and devices. These are indeed prevalent and rampant.

\section{F. Key Informant F}

Data Coding of Guide Questions ( $1^{\text {st }}$ set):

\begin{tabular}{|c|c|c|}
\hline RAW DATA & $\begin{array}{l}\text { PRELIMINARY } \\
\text { CODING }\end{array}$ & FINAL CODE \\
\hline $\begin{array}{l}\text { Mostly, it is stressful and new. As } \\
\text { instructors under the Maritime } \\
\text { department, we are knowledgeable } \\
\text { in tech support and management. } \\
\text { This allows us to be flexible and } \\
\text { wise of our time during class hours, } \\
\text { but it is vulnerable to so much } \\
\text { factors like personal finances and } \\
\text { internet connections. } \\
\text { Our role during the pandemic is to } \\
\text { be supportive in carrying the } \\
\text { administration's objectives inclined } \\
\text { to online education. }\end{array}$ & $\begin{array}{l}\text { - Increased awareness } \\
\text { on the need for } \\
\text { knowledge } \\
\text { technology. } \\
\text { - } \\
\text { Factors such as power } \\
\text { outages serve as } \\
\text { hindrance to online } \\
\text { education } \\
\text { - Fulfilling } \\
\text { administrative } \\
\text { objectives related to } \\
\text { online education }\end{array}$ & $\begin{array}{l}\text { - Holistic fulfillment } \\
\text { of the university's } \\
\text { objective on online } \\
\text { education amidst the } \\
\text { pandemic. }\end{array}$ \\
\hline
\end{tabular}

\section{Interpretation:}

Informant $\mathrm{F}$ finds the current state of online teaching both stressful and opportune to try new things in the teaching profession; most notable of the current curriculum. He claims that their expertise on technology as maritime instructors enables them to be proficient with time management, though is subjective at times due to the same reoccurring factors that plague the new system for online education.

Regardless, such tribulation serves only as a temporary impasse due to the sheer drive and motivation to instruct in the name of quality education.

Data Coding of Guide Questions ( $2^{\text {nd }}$ set):

\begin{tabular}{|c|c|c|}
\hline RAW DATA & $\begin{array}{l}\text { PRELIMINARY } \\
\text { CODING }\end{array}$ & FINAL CODE \\
\hline $\begin{array}{l}\text { I don't see too much problem } \\
\text { besides difficulties in maintaining } \\
\text { stable internet connection and } \\
\text { maintaining constant teaching } \\
\text { hours with students due to power } \\
\text { interruptions and lax behavior by } \\
\text { some. }\end{array}$ & $\begin{array}{l}\text { - Hindrances exist } \\
\text { amidst online } \\
\text { education } \\
\text { - Validation of } \\
\text { hindrances } \\
\text { - Personal health is } \\
\text { affected }\end{array}$ & $\begin{array}{l}\text { - Hindrances remain } \\
\text { consistent and felt } \\
\text { throughout the } \\
\text { course of the online } \\
\text { education } \\
\text { curriculum. }\end{array}$ \\
\hline
\end{tabular}

\section{Interpretation:}

With the inclusion of lax student behavior, the informant perceives the current situation of online education in USANT as one filled with hindering factors mentioned by previous informants. This would include, again: poor internet connection, power interruptions and the mentioned. 
Factors stated appear at a frequency so reoccurring that it says more that what meets the eye regarding Iriga city's social conditions; mostly involving constituents who make a living facing hardships and struggles concerning adaptation to the new normal.

\section{G. Key Informant G}

Data Coding of Guide Questions ( $1^{\text {st }}$ set $)$ :

\begin{tabular}{l} 
RAW DATA \\
\hline 1 , Of course our job is mostly \\
difficult but it can also be \\
rewarding.
\end{tabular}

For me, the new curriculum allows us instructors of the maritime department to use new teaching strategies and time management skills in order to cope with the new normal.

While time can be both flexible and encumbering, it is based on what the students and instructors have in their disposal during online teaching.

Mostly, we teach in the department where our internet is already provided by the school, but for students outside the school of course, it can be different and difficult.

That is why we must continue doing our job for the greater good of our institution.

\section{Interpretation:}

Informant $\mathrm{G}$ asserts that the pay-off for teaching in the current timeline can be both gratifying and mediocre at times. This is because the hardship that comes along online teaching can be drastic or tolerable at times. Regardless, said opportunity allows the instructor to incorporate various means and strategies in relaying proper and meaningful education and discourse through online platforms. This in mind, however, moments when hindering factors mentioned previously surface is where the hardships of online education thrive the most. As such, the informant believes flexibility and practicality is key to adapt to the pandemic's challenges for education.

Data Coding of Guide Questions ( $2^{\text {nd }}$ set):

\begin{tabular}{lllll}
\hline RAW DATA & PRELIMINARY & \multicolumn{2}{l}{ FINAL CODE } \\
& CODING & \\
\hline Most difficulties are very & $\bullet$ & Hindrances exist \\
persistent, like bad internet & amidst online & & Hindrances remain \\
connection, meaningless & education & consistent and felt \\
throughout & the \\
\hline
\end{tabular}




\begin{tabular}{|c|c|c|c|}
\hline $\begin{array}{l}\text { student to teacher } \\
\text { discussion due to bad signal } \\
\text { and power outages, lack of } \\
\text { direct supervision, and no } \\
\text { direct participation } \\
\text { especially since the nature } \\
\text { of the course requires all to } \\
\text { be more "hands-on" }\end{array}$ & $\begin{array}{ll}\text { - } & \text { Validation } \\
\text { hindrances } \\
\text { - } & \text { Maritime } \\
\text { education } \\
\text { hands-on }\end{array}$ & of & $\begin{array}{l}\text { course of the online } \\
\text { education } \\
\text { curriculum. }\end{array}$ \\
\hline
\end{tabular}

\section{Interpretation:}

Carrying a different take, the informant - while having stated re-visiting hindering factors - claims that the nature of maritime as a course is too "handson" and "involving" hence most students lose the value of truly embodying the essence of being a maritime student due to the sudden shift to online education.

Likewise, these factors are exacerbated by previous factors and is thus truly detrimental to online instructions and teaching as a whole.

\section{H. Key Informant $H$}

Data Coding of Guide Questions ( $1^{\text {st }}$ set):

\begin{tabular}{c} 
RAW DATA \\
\hline 1, For me, it is mostly difficult, but
\end{tabular} it is our job so we push through even if it is hard.

Allocating time for the work mostly depends on the students and our workload. It is sometimes easier than some, it can be too heavy at times.

I believe knowledge on technology is necessary for the new curriculum. Without it, we cannot teach properly and effectively, since we are far away from each other and we need internet to teach.

Our role is to always assist our students and teach them according to what is tasked in the units they are under in.

\section{PRELIMINARY FINAL CODE CODING}

- Increased awareness on the need for knowledge on technology.

- Factors such as power outages serve as hindrance to online education

- Teaching as a profession is a priority

- The unlimited range of online teaching

\section{Interpretation:}

Informant $\mathrm{I}$ is adamant in positing that the job of an instructor is an "obligation" one promises him/herself into. One can learn to love and appreciate the craft behind such profession which is inclusive of the relationships form among students and teachers respectively.

As such, the informant believes that the role of instructors must be supportive in nature. This is extremely crucial in the long-run due to the 
prevalence of "encumbering" mental and physical health factors to both students and instructors.

Alongside the claim, flexibility in time management is also present in the shift to online education due to the facets of online education, which involves "accessibility" everywhere and anytime. Since this is the case, knowledge on technological utilization is supreme in the endeavour.

Data Coding of Guide Questions ( $2^{\text {nd }}$ set):

\begin{tabular}{|c|c|c|}
\hline RAW DATA & $\begin{array}{l}\text { PRELIMINARY } \\
\text { CODING }\end{array}$ & FINAL CODE \\
\hline $\begin{array}{l}\text { There are many difficulties. } \\
\text { One of which is the most } \\
\text { common "internet } \\
\text { connection problem". } \\
\text { Power interruptions and } \\
\text { cheating during works and } \\
\text { exams happen also. }\end{array}$ & $\begin{array}{l}\text { - Hindrances exist } \\
\text { amidst online } \\
\text { education } \\
\text { - Validation of } \\
\text { hindrances }\end{array}$ & $\begin{array}{l}\text { - Hindrances remain } \\
\text { consistent and felt } \\
\text { throughout the } \\
\text { course of the online } \\
\text { education } \\
\text { curriculum. }\end{array}$ \\
\hline
\end{tabular}

Interpretation:

Over the course of the data-gathering process, the three most mentioned difficulties involve: internet connections problems, power interruptions and difficulties in facilitating works and assessments seem to be frequent and empirically observed by instructors of USANT's maritime department.

When traced, such factors are all present among the 8 other respondents; signifying the drastic impact of the difficulties to the overall state and value of online education.

Findings:

1) Results from the data show that most instructors believe that the experience can be rewarding, difficult and exciting. Most of the participants claim that the shift exemplifies the struggles to fulfill the work. Respectively, the statements are diverse in a sense that such lived experience is crucial in the teaching endeavor under USANT's Maritime department. Key Informant A believes that Maritime instructors, including himself, should be adaptive and inducive to change. This involves characteristics specific to patience, ample consideration to lenient behavior and flexibility to ebbing situations necessary for synchronous teaching which engages the instructor and the student in discussions through online means. With this, he claims that factors that continue to interrupt the sanctity and stability of online education can be combated should one be ready to embody said characteristics.

Key Informant B is a prime believer of technological knowledge as per the shift to online education and asserts that instructors in the department are left to technology's craft in order to relay their teachings efficiently. That said, their role as instructors - he claims - remains relevant; hence, instructors must be capable of adapting to circumstances instigated by online education.

Pertinent to the claim, he states that necessary equipment and devices are crucial in the maritime course hence major adjustments have been made by them to further amplify the institution's dictum of promoting "quality education" among students of all levels. 
Key Informant $\mathrm{C}$ avers that the experience of teaching online requires them to be more flexible and patient to the circumstances in the current situation. This, however, is a struggle due to the presence of obvious hindering factors discussed in findings \#2.

A unique take by the informant shows that one must be practical or pragmatic when teaching synchronously or asynchronously, as this will allow the instructor to create a right "frame of mind" modified especially for the new curriculum. As such, the informant states that one must be understanding and considerate of the situations caused by pandemic given the state of education in the nation.

Key Informant D postulates that the experience is difficult and stressful due to the need to amply adapt to the changes in the setting and methods of teaching. That said, she also believes that an instructor must be self-driven despite the tribulations imposed by the pandemic.

According to her, this must be seen as a task that must be done in order to test one's affinities and capacity for online teaching.

Key Informant E posits that the experience of shifting to online education is strenuous, albeit can also be exciting and convenient for instructors. As such, he claims that flexibility in time management is possible due to having instruct and teach in the comfort of one's control. This however, is hampered by pre-existing hindering factors mentioned previously.

The role of an instructor is still deemed significant in the current situation and according to him, USANT Maritime instructors are known for their strict and meticulous classroom management - a reputation well-deserved over the course of years.

Key Informant $\mathrm{F}$ says that the experience can serve as an opportune moment to improve his craft in teaching, though can totally be stressful in the long-run.

He goes on to tell that one's inclination to technology is truly relevant in the field due to the course's nature of integrating new technology to simulate maritime work respectively. Ultimately, the job of instructors, according to him, is to carry their institution's drive to educate students.

Key Informant $\mathrm{G}$ describes the experience as both rewarding and difficult. This is so due to his reasoning anchored on pragmatism, which pits one's obligation to teach with limited resources. This circumstance allows students and instructors of the department to integrate practical methods of learning and teaching essentials to establish thorough academic connection despite longdistances.

Difficulties are sure to lie in wait, hence he believes one's patience and discipline can be the deciding factor that which promotes success in the endeavor.

Key Informant $\mathrm{H}$ is steadfast in declaring that his obligation must be done with utmost dedication despite struggles after the shift. Time management for the work depends mostly on the instructor's workload and typically dictates how difficult or simple the work will be.

Knowledge on the use of technology must be tamed by all instructors since such asset is the primary way to establish connections with students across the 
region. With this, he asserts that instructors must be supportive to students who are most likely suffering twice or thrice as much as they do.

2.) Overall assessment of the findings shows that the challenges (hindering factors) present after the shift to online education are identified as internet connection problems, frequent power outages in Iriga city, absence of direct supervision to students by the instructor, knowledge deficiency related to the use of technology, limited online storage space, and stress to physical and mental health.

Key Informant A believes that poor internet connection is the proprietor of failure to effectively teach during the online education curriculum; resulting to the loss of quality discussions and discourse during synchronous sessions and lessons.

Key Informant B claims that poor internet connection, power outages, cheating and limited online storage space for files related to the course are constantly impacting effective online teaching. This is exacerbated by the fact that most students - even instructors - are affected by limited resources which are inevitably invested on devices and internet connections. This, alongside the worsening status quo of the pandemic, is primed by one's extent of knowledge towards the utilization of technology, in which when analysed, can be the basis for the "payoff" of working teaching amidst online education.

Key Informant $\mathrm{C}$ likewise states that poor internet connection, power outages and the lack of appropriate devices such as smartphones and laptops for online learning is extremely detrimental and prevalent for both instructor and student.

Since gadgets are media for both instruction and learning, failing to procure at least a device containing the specific specifications for adequate function and operation will mean a disadvantage for the student or instructor.

Key Informant D avers that poor internet connection, frequent power outages and one's personal health are factor to watch out when one is to engage in online learning and teaching.

Accordingly, an instructor's penchant for teaching is limited in as much as his or her mental and physical health is limited as well. This in mind, teaching becomes an act of sagacious care and planning involving one's holistic development and training.

Likewise, Key Informant E states the same set of factors are pervasive after the shift to online education, which are: poor internet connection, power outages, and personal health due to overuse and exposure to radiation through device and gadget use.

Key Informant $\mathrm{F}$ asserts the same factors presented, but with the inclusion of lax student behavior. This can be traced to the presence of the other mentioned factors which greatly impact the teaching and learning mentality of teachers and students; hence the need for virtues amidst the massive shift done for the sake of education through online means.

Key Informant $\mathrm{G}$ - with the inclusion of poor internet connection, power outages and absence of direct supervision - believes that the maritime course is strictly hands-on in nature. This implies that the course's value for what it is 
mainly observed through practicum and actual application of lessons and more all tied to face-to-face interactions.

He claims that the essence of the course is halved due to the shift to online education, but nonetheless, should be accomplished and bridged to students accordingly.

Similarly, Key Informant $\mathrm{H}$ avers that internet connection problems, power interruptions and difficulty in supervising student work and assessments are frequent struggles in the course.

While the first two factors are known for what they are, difficulty in supervising student work refers to the penchant of students to heat or stray away from normative and fair learning. According to him, this is instigated by the likewise-present difficulties caused by the pandemic to the general populace.

\section{Conclusion:}

1. The following conclusions were arrived at based on the findings of the study:

When assessed, the experiences are described in various ways and aspects. The shift to online modality and education is a test to USANT Maritime instructors in terms of bridging quality education of students under their tutelage. However, such shift is a hodge-podge of circumstances that can be described as the following:
A.1. Stressful
B.1. Rewarding
E.1. Challenging
C.1. New
F.1. Exciting
D.1. Difficult/ Perplexing
G.1. Convenient

The terms extracted after coding participants' data show how daunting the shift is. That is to say that the standard of education in the Maritime department is now dictated by prevailing factors present in online platforms and media integrated for online education. As such, factors presented in findings \#2 can essentially slink its way through online educative channels; potentially degrading the online education experience.

In connection, the experience and its respective descriptions are seen in the following categories:

A.2. Technical Support

B.2. Time commitment of faculty

C.2. Instructional strategies during online instruction

D.2. Role as an Online Instructor

E.2. Adjustment of teaching to online instruction

F.2. Synchronous vs asynchronous teaching

G.2. Feelings and thoughts on teaching online

Ultimately, the endeavor is an experience rooted on practicality and accessibility. It is both refreshing and difficult to do accordingly. Though the range for education is increased ten-fold; the same can be said of possible drawbacks, which shall be discussed in conclusion \# 2. 
2. The difficulties rooted on online education is obvious as a "boulder wedged between a dam." This is so because of COVID-19 pandemic which prompted an increase in the procurement and purchase of devices and internet connection for personal use. When analyzed, the virtual realm becomes an indispensable counterpart to education and work.

According to the data interpreted, teaching and instructing as part of USANT's Maritime department is crucially affected by prevailing hindering factors true for both teachers and students of the department. Since online education limits learning and teaching into a single channel. Hindering factors are strongly felt throughout the endeavor which are as follows:

\section{A.3. Poor internet connection \\ B.3. Frequent power outages or "black-outs" \\ C.3. Personal health (mental and physical health) \\ D.3. Absence of direct supervision by instructor to students \\ E.3. Cheating during assessments}

F.3. Loss of value in terms of the course's essence due to the shift

G.3. Intolerable lenient behavior among students and instructors alike

When analyzed, the presented factors are mostly tied to resources and investments used and made by students and teachers to smoothen online interactions amidst online education. Though the range for educational opportunities is guaranteed to have increased, hindering factors applicable to the virtual realm is exponentially felt through the passing of time. In a sense, the endeavor becomes a liability that seeks to exacerbate the negative aspects of the shift; true for both students and instructors.

Regardless these factors they are also manageable based on resources and teaching strategies. In overcoming these factors, recommendations are discussed.

\section{BIBLIOGRAPHY}

Bacus, R. C. (n.d.). Awareness and Stances of Higher Education Institution Faculty on Transnational Education.

Baralt, M., Gurzynski-Weiss, L., \& Kim, Y. (2016). Engagement with the language. Language Learning \& Language Teaching; John Benjamins Publishing Company: Amsterdam, The Netherlands, 209-239.

Bergamin, P. B., Ziska, S., Werlen, E., \& Siegenthaler, E. (2012). The relationship between flexible and self-regulated learning in open and distance universities. International Review of Research in Open and Distributed Learning, 13(2), 101-123.

Conaway, R. N., Easton, S. S., \& Schmidt, W. V. (2005). Strategies for enhancing student interaction and immediacy in online courses. Business Communication Quarterly, 68(1), 23-35.

Cui, L., Li, H., \& Song, Q. (2014). Developing the ability for a deep approach to learning by students with the assistance of MOOCs. World Trans. on Engng. and Technol. Educ, 12(4), 685-689.

Grgurović, M. (2014). An application of the Diffusion of Innovations theory to 
the investigation of blended language learning. Innovation in Language Learning and Teaching, 8(2), 155-170.

Kebritchi, M., Lipschuetz, A., \& Santiague, L. (2017). Issues and challenges for teaching successful online courses in higher education: A literature review. Journal of Educational Technology Systems, 46(1), 4-29.

Korolkov, A., Germanov, G., Langueva, O., Shevyakova, A., \& Poskrebysheva, N. (2020). Advantages and disadvantages of distance learning on students' and teachers' of the physical culture faculty opinion. BIO Web of Conferences, 26, 58.

Rasheed, R. A., Kamsin, A., \& Abdullah, N. A. (2020). Challenges in the online component of blended learning: A systematic review. Computers \& Education, 144, 103701.

Sammons, M. C., \& Ruth, S. (2007). The invisible professor and the future of virtual faculty. International Journal of Instructional Technology and Distance Learning, 4(1), 3-13.

Wanner, T., \& Palmer, E. (2015). Personalising learning: Exploring student and teacher perceptions about flexible learning and assessment in a flipped university course. Computers \& Education, 88, 354-369.

$\mathrm{Xu}$, D., \& Jaggars, S. S. (2014). Performance gaps between online and face-toface courses: Differences across types of students and academic subject areas. The Journal of Higher Education, 85(5), 633-659. 